\title{
SINONIM NOMINA BAHASA MELAYU MANADO
}

\author{
Lidya A. A. Pantouw \\ lidyapantouw@gmail.com \\ Pascasarjana Universitas Sam Ratulangi
}

\begin{abstract}
This research focuses on the problems of synonymy of the nouns in Malay Manado language. The objectives of the research are to describe the distinctive features among synonymous nouns in Malay Manado language. This research is descriptive research, of the type of the text analysis (content analysis), using the primary data (written) taken from Kamus Bahasa Malay Manado and the secondary data from the informants. The data were collected using the documentary method, listen and note taking method, and elicitation method. The analysis process was done using the orthographic similarity method because the standards are in the written form. Then, the similarity technique used was connect and compare equate technique (teknik hubung banding menyamakan (HBS)); and connect and compare distinguish technique (teknik hubung banding membedakan (HBB)). The analyses revealed the following: most Malay Manado nouns have near synonyms; there are general semantic features among the synonymous pairs of nouns; the pairs of the synonymous nouns are near synonyms because there are some distinguishing features (there are differences in aesthetic sense among the speakers, there are differences in the medium of sentences which use synonymous nouns, there are uncommon usage of nouns considered synonymous, and there are influences of dialects in the use of synonymous nouns). The use of synonymous nouns in the communication (both in spoken and written texts, both formal and informal usage), requires the accuracy on the part of the speakers due to the fact that there are distinguishing features in each of the synonymous pairs. This would avoid the obscurity and misunderstanding in receiving the information.
\end{abstract}

Keywords: synonymous nouns, near synonym, distinguishing components of meaning, connect and compare equate technique, connect and compare distinguish technique

\section{PENDAHULUAN}

Bahasa Melayu Manado digunakan berkomunikasi dalam hampir semua aktivitas kehidupan di Sulawesi Utara. Bahasa Melayu Manado sebagai bahasa perhubungan antaretnis di Sulawesi Utara juga sebagai bahasa ibu bagi masyarakat Sulawesi Utara. Kedudukan bahasa Melayu Manado dikategorikan sebagai bahasa regional di Sulawesi Utara sama seperti bahasa Melayu Betawi di Jakarta (Rattu, 2002:1). 
Bahasa Melayu Manado secara selintas memiliki kesamaan dengan bahasa Melayu di kawasan timur Indonesia seperti bahasa Melayu Papua, bahasa Melayu di Ambon, bahasa Melayu di Ternate, dan bahasa Melayu di Nusa Tenggara (Supardi, 193:2011). Sejalan dengan hal ini Alwi, (2003:2) berpendapat bahwa jenis kreol bahasa MelayuIndonesia, yakni Melayu Indonesia yang bercampur dengan bahasa setempat, didapati di Jakarta dan sekitarnya, Manado, Ternate, Ambon, Banda, Larantuka, dan Kupang.

Bahasa Melayu Manado atau dikenal juga dengan bahasa Manado banyak mendapat pengaruh Eropa, seperti bahasa Portugis, Spanyol, Belanda, Prancis, Inggris, dan Jerman dibandingkan bahasa Melayu lainnya di Indonesia (Tambayong, 2007:9), contoh kadera 'kursi' (Spanyol), gargantang 'tenggorokan', voor 'untuk' (Belanda), macis/matches 'korek api' (Inggris), hosa/husten 'batuk, nafas terganggu' (Jerman), fasung 'cantik', basombar 'berteduh' berasal dari sombre 'teduh' (Prancis). Kosakata ini masih digunakan berkomunikasi oleh masyarakat di Sulawesi Utara.

Studi tentang semantik barulah dalam taraf permulaan (Gloria Poejosoedarmo, 1988: 15). Oleh karena itu, masih banyak tantangan yang dihadapi untuk mengembangkannya. Hal ini berarti pula bahwa semantik masih merupakan ladang yang luas bagi penelitian kebahasaan. Masalah sinonim termasuk di dalam bidang kajian semantik yang dengan sendirinya juga merupakan lapangan yang masih terbuka bagi penelitian kebahasaan. Kata-kata yang bersinonim banyak mempunyai persamaan. Atas dasar persamaan itu, katakata tersebut membentuk kelompokkelompok yang masing-masing dalam pembicaraan selanjutnya disebut pasangan sinonim. Dari peristiwa ini terjadilah pasangan sinonim yang lainnya yang masingmasing dapat terdiri dari dua kata atau lebih sebagai anggotanya.

Menurut Verhaar (1983: 132) sinonim itu adalah ungkapan (kata, frasa, atau kalimat) yang kurang lebih sama maknanya dengan ungkapan yang lain. Jadi, meski beberapa kata bersinonim tetap akan memperlihatkan perbedaan. Misalnya, kata meninggal dunia dan kata mati memperlihatkan kesamaan makna yaitu nyawa telah hilang atau tidak hidup lagi, tetapi pemakaiannya berbeda. Kata meninggal hanya digunakan untuk manusia, dan tidak untuk binatang atau tumbuh-tumbuhan. Tidak mungkin orang mengatakan *"Pohon saya meninggal dunia kemarin." atau *"Sapi saya meninggal dunia." Kita hanya dapat mengatakan, "Si Ali mati kemarin." atau "Si Ali meninggal dunia kemarin." Akan tetapi, derajat makna kata mati dan meninggal dunia pada kalimat-kalimat ini pun berbeda. Penggunaan kata meninggal dunia dirasa lebih halus jika dibandingkan dengan kata mati. 
Dalam kegiatan komunikasi sehari-hari masyarakat pengguna bahasa Melayu Manado masih sering melakukan kesalahan dalam menggunakan kata-kata yang bersinonim itu. Semua itu dikarenakan kekurangtahuan mereka terhadap nilai makna suatu kata maupun kelompok kata. Seringkali bentuk kebahasaan yang berbeda-beda begitu saja dianggap sinonim, misalnya antara lao-lao 'tidak pasti' dengan nao-nao 'pikiran terganggu', antara ba minum 'minum' dengan ba gate 'menenggak minuman keras', serta antara ba haga 'melamun' dengan ba tarukira 'memerhatikan'. Pemakaian yang tumpang tindih dapat mengakibatkan adanya salah pengertian. Pasangan-pasangan kata tersebut dianggap bersinonim, padahal berdiri sendiri-sendiri karena memiliki karakteristik sendiri.

Adanya kesalahan dalam penentuan fitur semantis kata yang satu dengan kata lainnya tersebut dapat menimbulkan kejanggalan dan kesalahan penerimaan informasi. Oleh karena itu, penguasaan sinonim secara benar harusnya dimiliki oleh para pemakai bahasa untuk kegiatan komunikasi sehari-hari (baik lisan maupun tulis), terutama untuk bahasa Melayu Manado. Dikatakan demikian karena seperti yang diungkapkan Collinson (dalam Aminuddin, 2003: 118), kesamaan atau kemiripan makna bentuk kebahasaan yang satu dengan lainnya, bisa jadi masing-masing memiliki nuansa perbedaan tertentu.

Menurut pendapat Soedjito (1989: 7) Nuansa perbedaan itu dapat berhubungan dengan adanya ragam bahasa, nilai rasa, kolokial, makna dasar dan makna tambahan, dan distribusi kata. Sementara itu, menurut pendapat Palmer sebagaimana dikutip oleh Mansoer Pateda (2001: 226) ada lima kemungkinan yang menyebabkan adanya perbedaan makna pada pasangan sinonim, yaitu adanya (1) pengaruh dialek atau kebiasaan seempat; (2) perbedaan pada pemakaian; (3) perbedaan pada nilai kata; (4) perbedaan berdasarkan kolokialnya; dan (5) perbedaan karena hiponimi. Selanjutnya, menurut Abdul Chaer (2003: 298) ketidaksamaan makna kata-kata yang bersinonim terjadi karena beberapa faktor, yaitu (1) faktor waktu; (2) faktor tempat atau wilayah; (3) faktor keformalan; (4) faktor sosial; (5) faktor bidang kegiatan; dan (6) faktor nuansa makna. Ini berarti untuk menganalisis perbedaan makna kata yang termasuk dalam pasangan sinonim paling tidak harus didasarkan pada berbagai komponen pembeda makna tersebut.

Adapun kata-kata yang memiliki hubungan sinonim mencakup berbagai kelas kata. Menurut Hasan Alwi (2000: 4) kelas kata ada 8, yaitu (1) verba; (2) adjektiva; (3) nomina; (4) pronomina; (5) numeralia; (6) adverbia; (7) kata tugas; dan (8) interjeksi. 
Khusus pada kelas kata nomina, dilihat dari segi bentuknya terbagi lagi menjadi dua golongan, yaitu nomina dasar dan nomina turunan. Nomina dasar adalah nomina yang hanya terdiri atas satu morfem (monomorfemik) (Contoh: batu, meja, ibu, rumah, dan lain-lain). Sementara itu, nomina turunan adalah nomina yang terbentuk melalui afiksasi, perulangan, atau pemajemukan (Contoh: penemuan, penjualan, daratan, kesatuan, dan lain-lain).

Selanjutnya, makna kata nomina yang tergolong dalam pasangan sinonim memiliki kekhasan tersendiri yang memerlukan kejelian dan kedalaman analisis, sehingga persamaan dan perbedaan makna kata yang sekecil-kecilnya di antara pasangan sinonim tersebut dapat diperoleh. Hasil penganalisisan kata-kata dalam pasangan sinonim tersebut akan sangat membantu para pemakai bahasa dalam menggunakan kata-kata yang merupakan pasangan sinonim secara tepat. Jadi, tidaklah mengherankan jika hubungan makna yang banyak diteliti oleh para ahli linguistik Indonesia adalah hubungan kesinoniman (Umi Basiroh, 1992: 9).

Bertolak dari pemikiran di atas, peneliti terdorong untuk mendeskripsikan perbedaan makna kata dalam pasangan sinonim nomina bahasa Melayu Manado. Hal itu dilakukan dengan pertimbangan bahwa pemakaian nomina dalam komunikasi sehari-hari masyarakat pemakai bahasa Melayu Manado relatif tinggi dan nomina dalam sebuah kalimat cenderung menduduki fungsi subjek, objek, atau pelengkap. Namun, dalam penelitian ini tidak semua nomina dianalisis karena pembagiannya dapat tumpang tindih dan rinciannya sangat banyak. Jadi, nomina yang akan dianalisis dalam penelitian ini hanyalah nomina dasar (nomina yang hanya terdiri atas satu morfem (morfofonemik)).

Permasalahan dalam penelitian ini bagaimana bentuk dan ciri sinonim dalam bahasa Melayu Manado. Tujuan penelitian ini untuk mendeskripsikan bentuk dan ciri sinonim bahasa Melayu Manado. Manfaat penelitian ini untuk memberi informasi agar dapat meningkatkan pengetahuan dan penguasaan kosakata para pemakai bahasa Melayu Manado, khususnya seperangkat nomina yang bersinonim, sehingga para pemakainya dapat menggunakannya dalam penyusunan bahasa secara tepat.

\section{KERANGKA TEORI}

\section{Pengertian Sinonim}

Menurut pendapat Mansoer Pateda (2001: 222) secara etimologis, kata sinonim berasal dari bahasa Yunani Kuno yaitu 'onoma' yang berarti nama dan 'syn' yang 
berarti dengan. Adapun makna secara harfiah kata sinonim adalah nama lain untuk benda atau hal yang sama. Sementara itu, Palmer mengatakan bahwa "synonymy is used to mean sameness of meaning" 'kesinoniman digunakan untuk menunjukkan kesamaan'. Hal itu berarti bahwa dalam sebuah bahasa terdapat perangkat kata yang mempunyai arti yang berkesamaan atau berkesesuaian (Palmer, 1981: 88). Jadi, bentuk bahasa yang mengalami dan menjadi kelompok kesinoniman disebut sinonim. Kridalaksana (1984: 179) juga mengatakan bahwa sinonim adalah bentuk bahasa yang maknanya mirip atau sama dengan bentuk lain.

Selanjutnya, menurut Abdul Wahab (1995: 26) sinonim digunakan untuk menyatakan 'kesamaan arti' karena dalam sejumlah kata dijumpai adanya makna yang sama atau satu sama lain sama makna, atau ada hubungan di antara kata-kata yang mirip (dianggap mirip) maknanya. Misalnya, kata buruk dan jelek adalah dua kata yang bersinonim; kata bunga, kembang, dan puspa adalah tiga kata yang bersinonim. Hubungan makna antara dua kata atau lebih yang bersinonim bersifat dua arah. Kalau kata bunga bersinonim dengan kata kembang, maka kata kembang juga bersinonim dengan kata bunga. Akan tetapi, tidak semua kata-kata yang bersinonim dapat disubstitusikan, misalnya orang dapat mengatakan Saya betul; Saya benar; Kebetulan saya...; tetapi tidak mungkin orang mengatakan Kebenaran saya....

Mengenai pengertian sama makna, Zgusta dan Ullman (dalam Chaer, 1989: 86) menerangkan bahwa pada dasarnya kesamaan makna antara dua kata atau lebih yang bersinonim itu tidak bersifat mutlak. Ini berarti kata-kata yang bersinonim itu kesamaannya tidak seratus persen, hanya kurang lebih sama. Batasan yang sama juga diberikan oleh beberapa pakar. Sebagaimana diungkapkan oleh Soedjito (1989: 1) sinonim adalah dua kata atau lebih yang maknanya sama atau hampir sama (mirip). Parera pun menuliskan bahwa ujaran-ujaran baik dalam bentuk morfem terikat, kata, frase-frase, atau kalimat yang menunjukkan kesamaan atau kemiripan makna disebut sinonim atau bersinonim (1990: 49). Definisi yang sama dinyatakan pula oleh Verhaar (2000: 132) bahwa sinonim adalah ungkapan (biasanya sebuah kata, tetapi, frase, atau kalimat) yang kurang lebih sama maknanya dengan ungkapan yang lain.

Pada definisi yang dikemukakan oleh Verhaar tersebut, dapat dilihat adanya penggunaan urutan kata yang kurang lebih sama maknanya. Hal ini memang beralasan, karena kesamaan makna tidak berlaku secara sempurna. Artinya, meskipun maknanya sama, tetapi tetap memperlihatkan adanya perbedaan-perbedaan, apalagi jika dihubungkan dengan pemakaian kata-kata tersebut. Selanjutnya, menurut 
pendapat Bloomfield sebagaimana dikutip oleh I Dewa Putu Wijana dan Muhammad Rohmadi (2008: 29): "In contemporary linguistics it has become almost axiomatic that complete synonymy does not exist. Each Linguistic form has a constant and specific meaning. If the forms are phonemically different we suppose that their meanings are different. We suppose that there are no actual synonyms." (Di dalam linguistik kontemporer, sudah menjadi aksioma bahwa kesinoniman yang menyeluruh tidak pernah ada. Setiap bentuk kebahasaan memiliki makna yang khas dan tetap. Bentuk-bentuk yang memiliki struktur fonemis yang berbeda, dipastikan akan memiliki makna yang berbeda. Oleh karenanya, dapat diduga tidak ada kata-kata yang benar-benar bersinonim).

Jadi, yang perlu diperhatikan lebih saksama dari pengertian kesinoniman di atas adalah dinyatakannya makna yang "kurang lebih sama" atau "tidak identik sama" pada bentuk-bentuk yang bersinonim. Penekanan ini penting karena relasi kesinoniman tidak memiliki kesamaan makna yang sempurna. Dalam hal tersebut, para linguis bersepakat bahwa tidak terdapat dua kata atau lebih yang bersinonim secara mutlak atau absolut (Ullman, 1970: 141; dan Zgusta, 1971: 89). Sinonim yang umum dijumpai adalah sinonim dekat (near synonymy).

Dengan demikian, dapat disimpulkan bahwa sinonim adalah dua kata atau lebih yang mempunyai makna sama atau hampir sama (mirip). Adapun bentuk sinonim dapat meliputi kata, frase, dan kalimat yang maknanya kurang lebih sama. Akan tetapi, penelitian ini hanya akan mendeskripsikan kesinoniman nomina dasar secara leksikal, menurut makna leksikalnya, dan tidak membicarakan kesinoniman pada frase atau kalimat secara gramatikal.

Perlu diketahui bahwa anggota suatu pasangan sinonim akan dapat dilihat persamaan atau perbedaannya secara semantik dengan membandingkan makna referensialnya ataupun jika perlu makna dalam konteks pemakaiannya. Namun, perlu diingat bahwa menurut Gloria Poedjosoedarmo (1987: 1 dan 15) semua metode untuk menjelaskan makna itu ada kekurangannya dan studi tentang semantik masih dalam taraf permulaan. Oleh karena itu, dikatakan selanjutnya bahwa belum ada sebuah metode analisis yang dapat diterapkan pada suatu data dengan hasil yang memuaskan. Kreativitas dari pelaksananya sangat diperlukan.

\section{Jenis-jenis Sinonim}


Menurut pendapat Dad Muniah, Hari Sulastri, dan Atidjah Hamid (2000: 7) dalam bahasa Indonesia terdapat lima bentuk sinonim berikut ini.

1) Leksem bersinonim dengan leksem
baik
: bagus, indah, elok
mati
: meninggal, tewas, mampus, wafat, mangkat
abadi
: kekal, langgeng, lestari

2) Leksem tunggal bersinonim dengan leksem majemuk

$\begin{array}{ll}\text { gelandangan } & \text { : tunawisma } \\ \text { pelacur } & \text { : wanita tunasusila } \\ \text { pembantu } & : \text { pramuwisma }\end{array}$

3) Leksem tunggal bersinonim dengan frasa
asmara
: cinta berahi, cinta kasih
mualim
: ahli agama, guru agama, penunjuk jalan
muhibah
: rasa sahabat, rasa kasih

4) Leksem majemuk bersinonim dengan leksem tunggal

$\begin{array}{ll}\text { kereta angin } & \text { : sepeda } \\ \text { pokok hujan } & : \text { mendung } \\ \text { uang pokok } & \text { : modal }\end{array}$

5) Frase bersinonim dengan frase

$\begin{array}{ll}\text { kabar selenting } & \text { : kabar angin, desas-desus } \\ \text { kehilangan muka } & \text { : mendapat malu } \\ \text { bantuan moral } & \text { : sokongan batin }\end{array}$

Sementara itu, menurut pendapat Sumarlam, dkk (2003: 39 - 40), berdasarkan wujud satuan lingualnya, sinonim dapat dibedakan menjadi 5 macam berikut ini.

1) Sinonim antara morfem (bebas) dengan morfem (terikat)

Contoh:
a) Aku mohon kau mengerti perasaanku.
b) Kamu boleh bermain sesuka hatimu.
c) Dia terus berusaha mencari jati dirinya.

Pada contoh di atas, morfem (bebas) aku (a), kamu (b), dan dia (c), masing-masing bersinonim dengan morfem (terikat) $-k u,-m u$, dan -nya.

2) Sinonim kata dengan kata

Contoh: 
Meskipun Capeg, saya sudah terima bayaran. Setahun menerima gaji 80\%. SK pegnegku keluar. Gajiku naik.

Tampak pada tuturan di atas, kepaduan wacana tersebut antara lain didukung oleh aspek leksikal yang berupa sinonim antara kata bayaran pada kalimat pertama dengan kata gaji pada kalimat kedua dan ketiga. Kedua kata tersebut maknanya sepadan.

3) Sinonim kata dengan frasa atau sebaliknya

Contoh:

Kota itu semalam dilanda hujan dan badai. Akibat adanya musibah itu banyak gedung yang runtuh, rumah-rumah penduduk roboh, dan pohonpohon pun tumbang disapu badai.

Kepaduan wacana tersebut didukung oleh aspek leksikal yang berupa sinonim antara frasa hujan dan badai pada kalimat pertama dengan kata musibah pada kalimat berikutnya.

4) Sinonim frasa dengan frasa

Contoh:

Tina adalah sosok wanita yang pandai bergaul. Betapa tidak. Baru dua hari pindah ke sini, dia sudah bisa beradaptasi dengan baik.

Wacana di atas kepaduannya didukung oleh aspek leksikal sinonim antara frasa pandai bergaul pada kalimat pertama dengan frasa beradaptasi dengan baik pada kalimat ketiga. Kedua ungkapan itu mempunyai makna yang sepadan.

5) Sinonim klausa/kalimat dengan klausa/kalimat

Contoh:

Gunakan landasan teori yang tepat untuk memecahkan masalah tersebut. Pendekatan yang digunakan untuk menyelesaikan persoalan itu pun juga harus akurat.

Klausa memecahkan masalah tersebut pada kalimat pertama bersinonim dengan klausa menyelesaikan persoalan itu pada kalimat kedua. Kedua klausa yang bermakna sepadan itu mendukung kepaduan wacana, baik secara leksikal maupun semantis.

\section{Cara Mengetes Kesinoniman}


Pembahasan kesinoniman tersebut kadang dirancukan dengan pembahasan kehiponiman. Oleh karena itu, untuk mengetahui dua kata atau lebih itu merupakan hiponim atau sinonim mutlak atau tidak dapat digunakan cara ini.

1) Mensubstitusi

Jika suatu kata dapat diganti dengan kata lain dalam konteks kalimat yang sama dan makna konteks itu tidak berubah, kedua kata itu dapat dikatakan bersinonim. Contoh: datang bersinonim dengan tiba

a) (1) Mereka sudah datang.(dapat diterima)

(2) Mereka sudah tiba. (dapat diterima)

b) (1) Saya akan datang ke pertemuan itu. (dapat diterima)

(2) Saya akan tiba ke pertemuan itu. (tidak dapat diterima)

Kata datang dalam kalimat b.1 di atas dapat diterima, sedangkan kata tiba dalam kalimat b.2 tidak dapat diterima. Hal tersebut disebabkan oleh adanya ciri semantik yang membedakan. Ciri-ciri ini harus dapat dirumuskan sehingga dapat memperjelas pemakaian.

2) Menemukan antonim anggota pasangan sinonim.

3) Menderetkan kata yang bersinonim. (Ullman, 1970: 143 - 144).

Sementara itu, Lyons (1981: 40) berpendapat bahwa jika dua kalimat yang maknanya sama mempunyai struktur yang sama dan hanya berbeda karena dalam kalimat yang satu terdapat kata X dan kalimat yang lain terdapat kata $\mathrm{Y}$, maka kata $\mathrm{X}$ dan Y merupakan sinonim.

Contoh dalam bahasa Indonesia untuk pendapat Lyons tersebut adalah:

1) Ia acap melakukan kesalahan.

2) Ia sering melakukan kesalahan.

Kata acap dan sering dalam contoh kalimat di atas merupakan dua kata yang bersinonim.

Selanjutnya, menurut pendapat Sutiman dan Ririen Ekoyanantiasih (2007: 11), untuk mendeskripsikan hubungan kesinoniman, kita dapat menggunakan dua metode, yaitu metode analisis komponen makna dan metode kontekstual. Hal itu didasarkan pada pendapat para ahli linguistik bahwa para ahli linguistik yang ingin mendeskripsikan makna secara linguistik dapat memilih metode kontekstual, karena para penganut pendekatan kontekstual berasumsi bahwa ciri-ciri makna leksem terefleksikan secara penuh dalam konteks (Cruse, 1986: 1). 


\section{Pengertian Nomina Dasar}

Menurut pendapat Hasan Alwi, dkk. (2000: 218) nomina dasar adalah nomina yang hanya terdiri atas satu morfem. Sementara itu, menurut pendapat Syahidin Badru, Ebah Suhaebah, dan Non Martis (2000: 15) nomina dasar adalah nomina yang terdiri atas satu bentuk terkecil atau bentuk yang tak terbagi lagi, yaitu bentuk asal yang tidak mendapat afiks, tidak diulang, dan tidak digabungkan dengan bentuk dasar atau bentuk berafiks lain. Misalnya, kata rumah tidak dapat dibagi menjadi ru dan mah, baik ru maupun mah tidak mempunyai makna atau fungsi tertentu dalam bahasa Indenesia.

\section{METODE PENELITIAN}

Penelitian ini secara umum menggunakan metode deskriptif dengan dua macam metode pengumpulan data, yaitu metode lapangan dan metode pustaka. Metode lapangan digunakan untuk memperoleh data primer. Selanjutnya, teknik yang dipakai untuk mengumpulkan data, yaitu (1) teknik observasi, dipakai untuk mengamati sinonim nomina dasar bahasa Melayu Manado. Pasangan sinonim yang dianalisis dibatasi pada kelas kata yang relatif lebih banyak memiliki pasangan sinonim serta tinggi frekuensi pemakaiannya dalam komunikasi sehari-hari (2) teknik pencatatan, hasil pencatatan yang dilakukan dari berbagai sumber dicatat pada kartu-kartu data yang disiapkan (3) teknik restospeksi, digunakan untuk menyeleksi semua data yang diperoleh untuk mendapatkan data yang akurat.

\section{PEMBAHASAN}

\section{Pasangan Sinonim Nomina yang Terkait dengan Manusia (Bersifat Umum)}

a. Kata "anak"

Kata putra/putri bersinonim dengan kacili. Pasangan nomina tersebut mempunyai konsep dan komponen makna yang sama, sehingga bersinonim. Kata putra/putri dan kacili mempunyai komponen makna, seperti: bernyawa, berwujud, lakilaki/perempuan, tua/muda, manusia, sudah kawin/belum kawin, dan bisa tunggal/jamak. Namun, meski bersinonim, pasangan nomina tersebut tetap memiliki perbedaan dalam konteks pemakaiannya. Jadi, pasangan nomina tersebut hanya bersinonim dekat.

b. Kata "ayah" 
Terdapat dua pasang nomina yang mempunyai komponen makna yang sama, yaitu: (1) kata pai bersinonim dengan pa'; dan (2) kata papa bersinonim dengan papi.

Dua pasang nomina tersebut mempunyai konsep dan komponen makna yang sama, sehingga bersinonim.

1) Kata pai dan $p a$ ' mempunyai komponen makna, seperti: manusia, bernyawa, berwujud, tunggal, laki-laki, dewasa, kandung/tiri, kawin, dan merupakan kata Indonesia asli.

2) Kata papa dan papi mempunyai komponen makna, seperti: manusia, bernyawa, berwujud, tunggal, laki-laki, dewasa, kandung/tiri, kawin, dan merupakan kata serapan dari bahasa asing.

c. Kata "ibu"

Didapati bahwa terdapat dua pasang nomina yang mempunyai komponen makna yang sama, yaitu: (1) kata mai bersinonim dengan ma'; dan (2) kata mama bersinonim dengan mami. Dua pasang nomina tersebut mempunyai konsep dan komponen makna yang sama, sehingga bersinonim.

1) Kata mai dan ma' mempunyai komponen makna, seperti: manusia, bernyawa, berwujud, tunggal, perempuan, kawin, bisa kandung/tiri, dewasa, yang melahirkan/bukan yang melahirkan, yang menyusui/bukan yang menyusui, dan merupakan kata Indonesia asli.

2) Kata mama dan mami mempunyai komponen makna, seperti: manusia, bernyawa, berwujud, tunggal, perempuan, kawin, bisa kandung/tiri, dewasa, yang melahirkan/bukan yang melahirkan, yang menyusui/bukan yang menyusui, dan merupakan kata serapan dari bahasa asing.

d. Kata "wanita"

Terdapat tiga pasang nomina yang mempunyai komponen makna yang sama, yaitu:

(1) kata mace bersinonim dengan tanta; (2) kata maitua bersinonim dengan bini; (3) kata cewe bersinonim dengan nona. Ketiga pasang nomina tersebut mempunyai konsep dan komponen makna yang sama, sehingga bersinonim.

1) Kata mace dan tanta mempunyai komponen makna, seperti: manusia, berwujud, bernyawa, bersuami, dewasa, dan tua.

2) Kata maitua dan bini mempunyai komponen makna, seperti: manusia, berwujud, bernyawa, bersuami/ memiliki pasangan, dewasa, dan tua.

3) Kata cewe dan nona mempunyai komponen makna, seperti: manusia, berwujud, bernyawa, perawan, anak-anak, dan remaja. 
Namun, meski bersinonim, ketiga pasangan nomina tersebut tetap memiliki perbedaan dalam konteks pemakaiannya. Jadi, pasangan nomina tersebut hanya bersinonim dekat.

e. Kata "pria"

Ditemukan bahwa terdapat tiga pasang nomina yang mempunyai komponen makna yang sama, yaitu: (1) kata pace bersinonim dengan om; (2) kata paitua bersinonim dengan laki; (3) kata cowo bersinonim dengan nyong. Ketiga pasang nomina tersebut mempunyai konsep dan komponen makna yang sama, sehingga bersinonim.

1) Kata pace dan om mempunyai komponen makna, seperti: manusia, berwujud, bernyawa, dewasa, mempunyai zakar, dan sudah menikah/belum menikah.

2) Kata paitua dan laki mempunyai komponen makna, seperti: manusia, berwujud, bernyawa, remaja/dewasa, mempunyai zakar, dan sudah menikah.

3) Kata cowo dan nyong mempunyai komponen makna, seperti: manusia, berwujud, bernyawa, dewasa, mempunyai zakar, dan belum menikah.

Namun, meski bersinonim, keempat pasangan nomina tersebut tetap memiliki perbedaan dalam konteks pemakaiannya. Jadi, pasangan nomina tersebut hanya bersinonim dekat.

f. Kata "teman"

Berdasarkan uraian unsur-unsur komponen makna yang berada dalam satu kolokasi makna "kawan; sahabat", terlihat bahwa terdapat sepasang nomina yang mempunyai komponen makna yang sama, yaitu tamang bersinonim dengan konco. Sepasang nomina tersebut mempunyai konsep dan komponen makna yang sama, sehingga bersinonim. Kata tamang dan konco mempunyai komponen makna, seperti: manusia, berwujud, bernyawa, baru kenal, teman satu pekerjaan, dan hubungannya biasa. Namun, meski bersinonim, pasangan nomina tersebut tetap memiliki perbedaan dalam konteks pemakaiannya. Jadi, pasangan nomina tersebut hanya bersinonim dekat.

\section{Pasangan Sinonim Nomina yang Terkait dengan Nomina Tak} Bernyawa(Konkret) dan Bersifat Umum

a. Kata "rumah"

Ditemukan bahwa terdapat sepasang nomina yang mempunyai komponen makna yang sama, yaitu: kata rumah bersinonim dengan sabua. Pasangan nomina tersebut 
mempunyai konsep dan komponen makna yang sama, sehingga bersinonim. Kata rumah dan sabua mempunyai komponen makna, seperti: bangunannya permanen ataupun tidak, berbahan semen atau kayu/bambu, ukurannya besar atau kecil, kamarnya banyak atau sedikit, untuk tempat tinggal, berwujud, dapat dilihat, serta benda mati. Namun, meski bersinonim, kedua pasangan nomina tersebut tetap memiliki perbedaan dalam konteks pemakaiannya. Jadi, pasangan nomina tersebut hanya bersinonim dekat.

b. Kata "uang"

Terdapat sepasang nomina yang mempunyai komponen makna yang sama, yaitu: kata uang bersinonim dengan doi. Sepasang nomina tersebut mempunyai konsep dan komponen makna yang sama, sehingga bersinonim. Kata uang dan doi mempunyai komponen makna, seperti: berwujud, benda mati, dapat dilihat, digunakan pada masa sekarang, alat pembayaran yang sah, serta berbahan kertas dan logam. Namun, meski bersinonim, sepasang nomina tersebut tetap memiliki perbedaan dalam konteks pemakaiannya. Jadi, pasangan nomina tersebut hanya bersinonim dekat.

c. Kata "warung"

Terdapat dua pasangan nomina yang mempunyai komponen makna yang sama, yaitu (1) kata warong bersinonim dengan kios; serta (2) kata ruma makang bersinonim dengan ruma kopi. Dua pasangan nomina tersebut mempunyai konsep dan komponen makna yang sama, sehingga bersinonim.

1) Kata warong dan kios mempunyai komponen makna, seperti: menjual makanan dan minuman, pembeli dilayani, tempat tidak luas, berwujud, dapat dilihat, benda mati, dan untuk usaha.

2) Kata ruma makang dan ruma kopi mempunyai komponen makna, seperti: menjual makanan dan minuman, pembeli dilayani dan melayani sendiri, tempat ada yang luas/sempit, berwujud, dapat dilihat, benda mati, dan untuk usaha. Namun, meski bersinonim, dua pasangan nomina tersebut tetap memiliki perbedaan dalam konteks pemakaiannya. Jadi, pasangan nomina tersebut hanya bersinonim dekat.

\section{SIMPULAN}

Berdasarkan analisis data dan pembahasan yang dilakukan dapat disimpulkan bahwa komponen makna dan substitusi kata dalam kalimat menjadi patokan atau cara untuk melihat sejauh mana kesinoniman itu terdapat. Komponen makna yang 
membedakan anggota pasangan sinonim yang satu dengan anggota yang lainnya itulah yang memperlihatkan sifat hubungan kesinoniman.

Selanjutnya, dari penelitian ini dapat disimpulkan beberapa hal berikut ini.

1. Terkait dengan ciri pembeda makna nomina bahasa Melayu Manado yang bersinonim.

a. Kebanyakan nomina dalam Bahasa Indonesia adalah bersinonim dekat (near synonym) dan tidak ada yang bersinonim mutlak.

b. Terdapat ciri semantik generic (umum) di antara pasangan nomina yang bersinonim, antara lain: (1) Pasangan sinonim nomina yang terkait dengan manusia mempunyai ciri umum: benda berwujud (konkret), bernyawa, dan manusia (2) Pasangan sinonim nomina yang terkait dengan nomina tak bernyawa (konkret) mempunyai ciri umum: benda berwujud (konkret), benda mati, dan dapat dilihat.

2. Terkait dengan pemakaian kata-kata yang termasuk dalam suatu pasangan sinonim nomina bahasa Indonesia.

a. Pasangan nomina dalam Bahasa Indonesia yang bersinonim, ternyata hanya bersinonim dekat (near synonym). Hal itu disebabkan adanya ciri pembeda dalam pemakaian kata-kata bersinonim itu, yang meliputi: (1) perbedaan rasa estetis pemakai bahasa (misalnya pemakaian kata untuk tujuan arkhaik, puitik, hormat, atau santai); (2) perbedaan media kalimat yang menggunakan kata-kata bersinonim; (3) ketidaklaziman penggunaan kata yang dianggap bersinonim; dan (4) adanya pengaruh dialek dalam penggunaan kata-kata bersinonim.

b.Ditemukan dua kelompok nomina dasar dalam pemakaian kata-kata yang termasuk dalam suatu pasangan sinonim nomina bahasa Melayu Manado, yaitu: (1) Nomina dasar asli, misalnya manusia, warung, rumah, dan lain-lain.

(2) Nomina dasar serapan, misalnya papi, mami, kafe, dan lain-lain.

\section{DAFTAR PUSTAKA}

Abdul Chaer. 1989. Hubungan Bahasa, Kebudayaan, dan Pemikiran. Jakarta: Rineka Cipta.

Abdul Chaer dan Leonie Agustina. 1995. Sosiolinguistik: Perkenalan Awal. Jakarta: PT. Rineka Cipta.

Abdul Wahab. 1995. Teori Semantik. Surabaya: Airlangga University Press.

Alwi, dkk. 2003.Tata Bahasa Baku Bahasa Indonesia. Edisi Ketiga. Jakarta: Balai Pustaka 
Aminuddin. 2003. Semantik: Pendekatan Studi tentang Makna. Bandung: Sinar Baru Algensindo.

Cruse, D. Alan. 1986. Lexical Semantics. New York: Cambridge University Press.

Dad Muniah, Hari Sulastri, dan Atidjah Hamid. 2000. Kesinoniman dalam Bahasa Indonesia. Jakarta: Pusat Bahasa Depdiknas.

Gloria Poedjosoedarmo. 1982. Beberapa Masalah Sintaksis Bahasa Jawa. Jakarta: Pusat Pembinaan dan Pengembangan Bahasa Departemen Pendidikan dan Kebudayaan.

Harimurti Kridalaksana. 1984. Kamus Linguistik. Jakarta: Gramedia.

Hasan Alwi, dkk. 2000. Tata Bahasa Baku Bahasa Indonesia. Jakarta: Balai Pustaka.

I Dewa Putu Wijaya dan Muhammad Rohmadi. 2008. Semantik: Teori dan Analisis. Surakarta: Yuma Pustaka.

Lyons, John. 1977. Semantics: Jilid 1. Cambridge: Cambridge University Press.

Mansoer Pateda. 2001. Semantik Leksikal. Jakarta: PT. Rineka Cipta.

Nida, M. A. 1975. Componential Analysis of Meaning. Paris: Mouton.

Palmer, F. R. 1981. Semantics. London: Cambridge University Press.

Parera, J. D.. 1990. Teori Semantik. Jakarta: Erlangga.

Rattu. A.B.G. 2002. Tata Bahasa Melayu Manado. Laporan Penelitian. Fakultas Bahasa dan Seni Universitas Negeri Manado. Tidak diterbitkan

Soedjito. 1989. Sinonim. Bandung: CV. Sinar Baru.

Sumarlam, dkk. 2003. Analisis Wacana: Teori dan Paraktik. Solo: Pustaka Cakra Surakarta.

Supardi. 2011. Afiksasi dalam bahasa Melayu Papua. Metalingua. Jurnal Bahasa dan Sastra. Volume 9 Nomor 2. Bandung: Balai Bahasa Bandung.

Sutiman dan Ririen Ekoyanantiasih. 2007. Kesinoniman Nomina Noninsani dalam Bahasa Indonesia. Jakarta: Pusat Bahasa Departemen Pendidikan Nasional.

Syahidin Badru, Ebah Suhaebah, dan Non Martis. 2000. Nomina dan Pemakaiannya dalam Bahasa Indonesia. Jakarta: Pusat Bahasa Depdiknas.

Tambayong, Yapi. 2007. Kamus Bahasa dan Budaya Manado.Gramedia: Jakarta

Ullman, Stephen. 1970. Semantics: an Introduction to the Science of Meaning. Oxford: Basil Blackwell.

Umi Basiroh. 1992. "Telaah Baru dalam Tata Hubungan Leksikal Kehiponiman dan Kemeroniman" Tesis Magister Program Studi Linguistik UI. Jakarta: Universitas Indonesia. 
Verhaar, J. W. M. 1983. Pengantar Linguistik: Jilid Pertama. Yogyakarta: Gadjah Mada University Press.

Verhaar, J. W. M. 2000. Pengantar Linguistik. Yogyakarta: Gadjah Mada University Press. Zgusta, Ladislav, et al. 1971. Manual of Lexicography. Paris: Mouton. 